\title{
열차폐코팅용 $\left(\mathrm{La}_{1-\mathrm{x}} \mathrm{Gd}_{\mathrm{x}}\right)_{2} \mathrm{Zr}_{2} \mathrm{O}_{7}$ 산화물의 상형성과 열전도도
}

\author{
권창섭 $a, b \cdot$ 이성민 ${ }^{a} \cdot$ 오윤석 ${ }^{a} \cdot$ 김형태 ${ }^{a} \cdot$ 장병국 ${ }^{c} \cdot$ 김성원 $a, *$

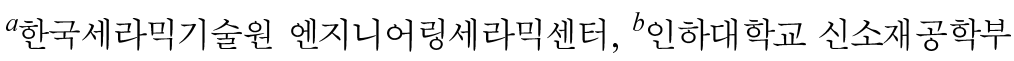 \\ ${ }^{c}$ 물질 · 재료연구기구 (NIMS) 선진고온재료유닛트
}

\section{Phase Evolution and Thermal Conductivities of $\left(\operatorname{La}_{1-x} G_{x}\right)_{2} Z_{2} O_{7}$ Oxides for Thermal Barrier Coatings}

\author{
Chang-Sup Kwon ${ }^{a, b}$, Sung-Min Lee ${ }^{a}$, Yoon-Suk Oh ${ }^{a}$, Hyung-Tae Kim ${ }^{a}$, \\ Byung-Koog Jang ${ }^{c}$, and Seong won Kim ${ }^{a, *}$ \\ ${ }^{a}$ Engineering Ceramic Center, Korea Institute of Ceramic Engineering and Technology, Icheon, \\ Gyeonggi-do 467-843, Korea \\ ${ }^{b}$ School of Materials Science and Engineering, In-Ha University, Incheon, Korea \\ ${ }^{c}$ High Temperature Materials Unit, National Institute for Materials Science, Tsukuba 305-0047, Japan \\ (Received October 23, 2012; Revised November 7, 2012; Accepted November 21, 2012)
}

\begin{abstract}
With increase in operating temperature of gas turbine for higher efficiency, it is necessary to find new materials of TBC for replacement of YSZ. Among candidate materials for future TBCs, zirconate-based oxides with pyrochlore and fluorite are prevailing ones. In this study, phase structure and thermal conductivities of $\left(\operatorname{La}_{1-\mathrm{x}} \mathrm{Gd}_{\mathrm{x}}\right)_{2} \mathrm{Zr}_{2} \mathrm{O}_{7}$ oxide system are investigated. $\left(\mathrm{La}_{1-\mathrm{x}} \mathrm{Gd}_{\mathrm{x}}\right)_{2} \mathrm{Zr}_{2} \mathrm{O}_{7}$ system are comprised by selecting $\mathrm{La}^{3+} / \mathrm{Gd}^{3+}$ as A-site ions and $\mathrm{Zr}^{4+}$ as $\mathrm{B}$-site ion in $\mathrm{A}_{2} \mathrm{~B}_{2} \mathrm{O}_{7}$ pyrochlore structures. With powder mixture from each oxide, $\left(\mathrm{La}_{1-\mathrm{x}} \mathrm{Gd}_{\mathrm{x}}\right)_{2} \mathrm{Zr}_{2} \mathrm{O}_{7}$ oxides are fabricated via solid-state reaction at $1600^{\circ} \mathrm{C}$. Either pyrochlore or fluorite or mixture of both appears after heat treatment. For the developed phases along $\left(\mathrm{La}_{1-\mathrm{x}} \mathrm{Gd}_{\mathrm{x}}\right)_{2} \mathrm{Zr}_{2} \mathrm{O}_{7}$ compositions, thermal conductivities are examined, with which the potential of $\left(\mathrm{La}_{1-\mathrm{x}} \mathrm{Gd}_{\mathrm{x}}\right)_{2} \mathrm{Zr}_{2} \mathrm{O}_{7}$ compositions for TBC application is also discussed.
\end{abstract}

Keywords: Thermal barrier coatings, Rare-earth oxides, Pyrochlore-fluorite, Thermal conductivities

\section{1. 서 론}

낮은 열전도도와 모재금속과 비슷한 높은 열팽창계수 및 비교적 풍부한 자원을 지닌 이트리아 안정화 지르코니 아(yttria-stabilized zirconia, YSZ)는 발전용 또는 항공용 가스터빈에 적용되는 열차폐코팅(thermal barrier coating) 소재로 사용되어 왔다[1]. 열차폐 코팅은 고온가스에 노출 되는 가스터빈의 금속부품을 열로부터 보호하고 사용온도 를 높여 가스터빈의 신뢰성과 에너지효율을 향상시키는 역할을 한다[2,3]. 가장 널리 사용되는 6 8 wt.\% $\mathrm{Y}_{2} \mathrm{O}_{3}$ (혹은 3.4 4.5 mol\% $\mathrm{Y}_{2} \mathrm{O}_{3}$ ) 가 첨가된 $\mathrm{YSZ}$ 의 경우, 고온에 서 준안정상인 정방정(tetragonal)상이 안정상인 정방정과 입방정(cubic)상으로 분리되어 냉각시에 정방정상이 단사 정(monoclinic)상으로 전이되어 이에 따르는 부피변화로 $\mathrm{TBC}$ 층에 균열이 야기되는 문제로 사용온도가 $\sim 1200^{\circ} \mathrm{C}$ 정 도로 제한된다[4, 5].

최근에 개발되는 가스터빈의 작동온도 $\left(>1300^{\circ} \mathrm{C}\right)$ 에서는 기존의 YSZ 사용이 어려우므로 새로운 열차폐 소재탐색 에 대한 연구가 활발히 진행되고 있다. $1300^{\circ} \mathrm{C}$ 이상에 적 용될 수 있는 열차폐 코팅소재는 높은 녹는점, 낮은 열전 도도, 금속모재와 비슷한 높은 열팽창계수, 상안정성, 화 학적 안정성, 낮은 소결성 등의 특성을 지녀야 한다 $[3,5]$. 이러한 요구조건에 만족하는 여러 소재중 특히 pyrochlore 혹은 fluorite구조의 zirconate계 산화물에 관한 연구가[6-9]

*Corresponding Author : Seongwon Kim, TEL: +82-31-645-1452, FAX: +82-31-645-1492, E-mail: woods3@kicet.re.kr 


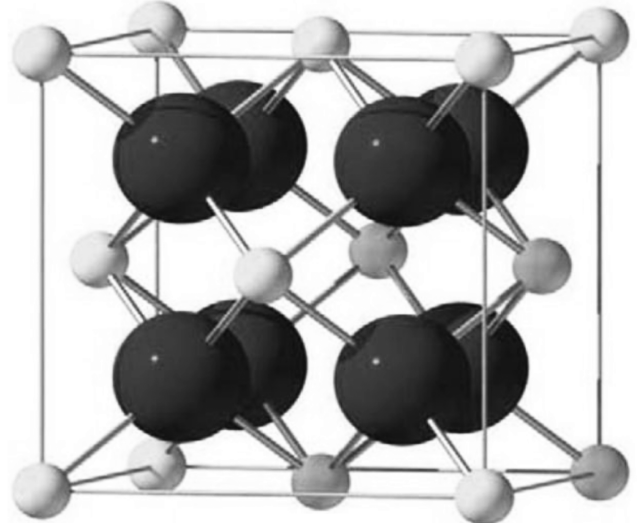

(a)

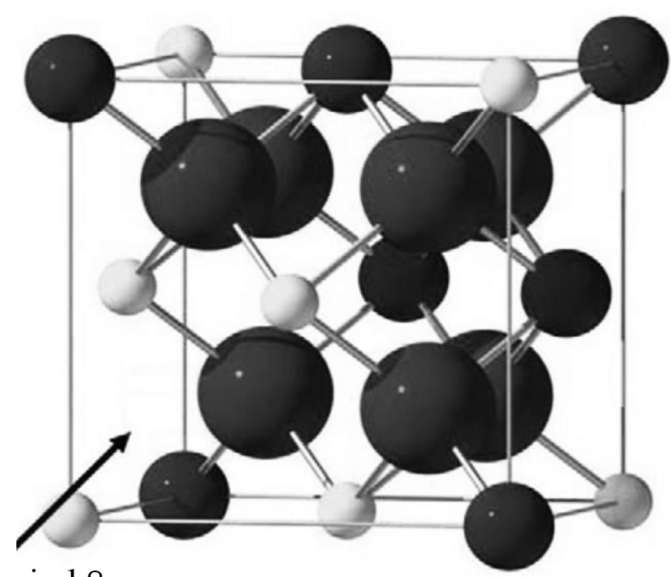

(b)

unoccupied $8 \mathrm{a}$

Fig. 1. (a) The unit cell of fluorite structure and (b) one-eighth of the unit cell of the pyrochlore, $A_{2} B_{2} O_{7}$ structure, where the largest spheres are oxygen ions and the others are rare-earth cations[13].

활발히 이루어지고 있다.

Pyrochlore 구조는 fluorite 구조와 유사한 결정구조로 pyrochlore와 fluorite 상은 각각 $\mathrm{Fd} \overline{3} \mathrm{~m}$ (\#227)과 $\mathrm{Fm} \overline{3} \mathrm{~m}$ (\#225) 공간군을 지니는 입방정구조이며 $\mathrm{A}_{2} \mathrm{~B}_{2} \mathrm{O}_{7}, \mathrm{AO}_{2}$ 의 화학일반식으로 표현된다[10-12]. 그림 1에 pyrochlore와 fluorite 결정구조의 개략도를 보였다[13]. Fluorite구조의 경우 단위포 내에 금속 양이온으로 이루어진 8개의 사면 체 위치(tetrahedral site, $8 \mathrm{a}$ 위치)가 모두 산소 이온으로 채 워져 있는 반면, pyrochlore 구조에서는 그중 하나가 빈 산 소공극(oxygen vacancy)이 존재한다. 이러한 구조의 산화
물이 낮은 열전도도를 지니는 것은 결정구조 내의 점결함 (point defect)에 의한 포논산란(phonon scattering)에 의한 것으로 알려져 있다 $[6,13] . \mathrm{A}_{2} \mathrm{~B}_{2} \mathrm{O}_{7}$ 의 화학식으로 표현되 는 산화물의 경우에 $\mathrm{A}, \mathrm{B}$ 위치에 존재하는 금속 양이온의 상대적인 이온반경에 의하여 pyrochlore나 fluorite로 안정 한 상이 결정되므로, 상당히 광범위한 조성영역에 대해서 pyrochlore 구조를 지니는 산화물을 발견할 수 있다.

본 연구에서는 pyrochlore와 fluorite상을 지니는 $\left(\mathrm{La}_{1-\mathrm{x}} \mathrm{Gd}_{\mathrm{x}}\right)_{2} \mathrm{Zr}_{2} \mathrm{O}_{7}(\mathrm{x}=0.0,0.5,1.0)$ 산화물의 상형성과 열전 도도 특성을 살펴보았다. $\mathrm{La}_{2} \mathrm{Zr}_{2} \mathrm{O}_{7}(\mathrm{LZ}),\left(\mathrm{La}_{0.5} \mathrm{Gd}_{0.5}\right)_{2} \mathrm{Zr}_{2} \mathrm{O}_{7}$, $\mathrm{Gd}_{2} \mathrm{Zr}_{2} \mathrm{O}_{7}(\mathrm{GZ})$ 세 조성의 시편에 대한 상형성과 미세구조 를 평가하였다. 또한 비열, 열확산도, 열전도도 등의 고온 열물성을 평가하고 고온에서 장시간 노출시의 상변화를 살피어 열차폐코팅용 소재로의 응용가능성을 검토하고자 하였다.

\section{2. 실험방법}

본 연구에서는 $\mathrm{La}_{2} \mathrm{O}_{3}$ (Kojundo Chemical Lab. Co., LTD, 99.9\%, $11 \mu \mathrm{m}$ ), $\mathrm{Gd}_{2} \mathrm{O}_{3}$ (Kojundo Chemical Lab. Co., LTD, 99.9\%, 2 3 $\mu \mathrm{m}$ ), $\mathrm{ZrO}_{2}$ (Kojundo Chemical Lab. Co., LTD, 98\%, $5 \mu \mathrm{m}) 3$ 종의 산화물을 이용하여 $\left(\mathrm{La}_{1-\mathrm{x}} \mathrm{Gd}_{\mathrm{x}}\right)_{2} \mathrm{Zr}_{2} \mathrm{O}_{7}(\mathrm{x}=0.0$, $0.5,1.0)$ 복합산화물을 합성시켰다. 표 1 의 조성이 되도록 칭량하여 지르코니아 볼과 IPA(Isopropyl alcohol)를 혼합 매질로 사용해 24 시간동안 볼밀(ball mill)을 이용해 습식 혼합 후 교반하면서 가열하여 용매를 증발시켰다. 용매가 증발된 혼합물을 $80^{\circ} \mathrm{C}$ 의 건조기에서 24 시간동안 건조하 였다. 건조된 분말을 유발로 분쇄한 후, 분당 $5^{\circ} \mathrm{C}$ 승온속 도로 $1400^{\circ} \mathrm{C}$ 에서 2 시간 유지 후 냉각하여 하소처리 하였 다. 하소한 분말은 알루미나 유발을 이용해 분쇄하고 체거 름하여 조립화한 후 $50 \mathrm{MPa}$ 로 1 분간 일축가압성형한 후 산화분위기의 전기로에서 분당 $5^{\circ} \mathrm{C}$ 로 승온하여 $1600^{\circ} \mathrm{C}$ 에 서 2 시간동안 소결한 후 냉각시켰다.

소결시편에 대하여 겉보기밀도, 상형성, 미세구조, 고온 열전도도 특성을 살폈다. 겉보기 밀도 $(\rho)$ 는 증류수를 이용 하여 아르키메데스 법으로 구하였다. X-선회절(X-ray diffractometer, D/MAX-2500/PC, Rigaku, Japan)을 통하여 하소분말과 소결체의 상형성을 살폈다. 주사전자현미경

Table 1. Compositions of rare-earth oxides used in this study

\begin{tabular}{|c|c|c|c|c|c|c|c|}
\hline \multirow{2}{*}{$\#$} & \multirow{2}{*}{ ID } & \multicolumn{3}{|c|}{ Weight percent for a batch(\%) } & \multirow{2}{*}{ Target composition } & \multirow{2}{*}{$\begin{array}{l}\text { Apparent density after } \\
\text { heat treatment }\left(\mathrm{g} / \mathrm{cm}^{3}\right)\end{array}$} & \multirow{2}{*}{ Porosity $(\%)$} \\
\hline & & $\mathrm{La}_{2} \mathrm{O}_{3}$ & $\mathrm{ZrO}_{2}$ & $\mathrm{Gd}_{2} \mathrm{O}_{3}$ & & & \\
\hline 1 & $\mathrm{LZ}$ & 57.0 & 43.0 & - & $\mathrm{La}_{2} \mathrm{Zr}_{2} \mathrm{O}_{7}$ & 6.021 & 7.3 \\
\hline 2 & LGZ & 31.6 & 48.0 & 20.4 & $\left(\mathrm{La}_{0.5} \mathrm{Gd}_{0.5}\right)_{2} \mathrm{Zr}_{2} \mathrm{O}_{7}$ & 6.332 & 38.2 \\
\hline 3 & GZ & - & 54.0 & 46.0 & $\mathrm{Gd}_{2} \mathrm{Zr}_{2} \mathrm{O}_{7}$ & 6.642 & 30.0 \\
\hline
\end{tabular}


(Scanning electron microscope, JSM-6390, JEOL, Japan)을 통하여 연마된 소결체 시편의 미세구조를 관찰하였다. 라 만형광분광기(Raman Microscope Enclosure, RE-04, Renishaw, U.K.)를 통하여 각 산화물 내의 결합특성을 평가하였다.

고온열물성으로 비열, 열확산도를 측정하고 열전도도를 구하였다. 비열과 열확산도는 레이저플레시법(Laser flash analysis, LFA 457 Micro Flash, Netzsch, Germany)을 이용 하여 $1000^{\circ} \mathrm{C}$ 까지 가열된 시편의 온도에 따라 측정하였다. 열확산도 측정시편에 조사되는 레이저가 투과없이 흡수되 고 광원 반대편의 적외선 검출기로 흑체 복사가 되도록 연마된 시편 양쪽에 흑연 코팅을 하였다. 시편의 열전도도 $(\mathrm{K})$ 는 측정된 겉보기 밀도 $(\rho)$, 비열 $\left(\mathrm{C}_{\mathrm{p}}\right)$, 열확산도 $(\lambda)$ 를 통 하여 식 (1)과 같이 계산하였다.

$$
\mathrm{K}=\rho \cdot \mathrm{C}_{\mathrm{p}} \cdot \lambda
$$

\section{3. 결과 및 고찰}

\section{1. $\left(\mathrm{La}_{1-\mathrm{x}} \mathrm{Gd}_{\mathrm{x}}\right) \mathrm{Zr}_{2} \mathrm{O}_{7}$ 산화물의 상형성과 미세구조}

서론에서 언급한 바와 같이 pyrochlore와 fluorite 결정구 조는 유사하지만 pyrochlore의 경우 양이온의 규칙적 배열 (ordering)과 특정위치의 산소이온 공극이 존재하는 것이 가장 큰 차이이다. $\mathrm{La}_{2} \mathrm{Zr}_{2} \mathrm{O}_{7}$ 를 예로 들어 설명하면, $\mathrm{La}^{3+}$ 양이온은 결정학적 특정위치, $16 \mathrm{~d}$ 자리 $(1 / 2,1 / 2,1 / 2)(\mathrm{A}$ 자리)를, $\mathrm{Zr}^{4+}$ 양이온은 $16 \mathrm{c}$ 자리 $(0,0,0)$ (B 자리)를 차 지하고 있는 정렬된 구조(ordered structure)이다. 산소 음 이온의 경우에는 두 개의 $48 \mathrm{f}$ 자리 $(\mathrm{x}, 1 / 8,1 / 8)$ 와 $8 \mathrm{~b}$ 자 리 $(3 / 8,3 / 8,3 / 8)$ 에 위치하며 pyrochlore 구조에서 산소 음 이온 위치와 격자상수는 $\mathrm{A}, \mathrm{B}$ 양이온의 상대적인 크기로 결정되고 특히 비어있는 산소 음이온 자리인 $8 \mathrm{a}$ 자리에

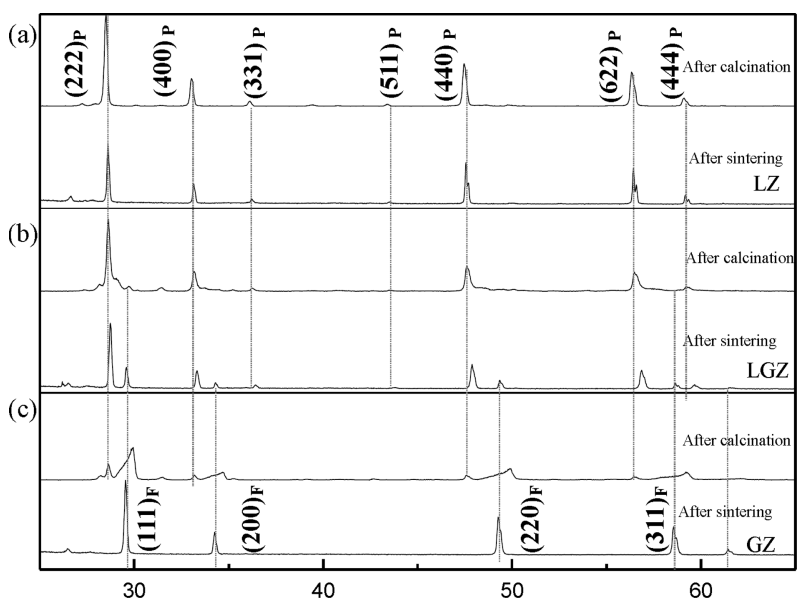

Fig. 2. Comparison of XRD patterns between calcined and sintered $\left(\mathrm{La}_{1-\mathrm{x}} \mathrm{Gd}_{\mathrm{x}}\right)_{2} \mathrm{Zr}_{2} \mathrm{O}_{7}$ samples for (a) $\mathrm{x}=0.0\left(\mathrm{La}_{2} \mathrm{Zr}_{2} \mathrm{O}_{7}, \mathrm{LZ}\right)$, (b) $\mathrm{x}=0.5$ (LGZ), and (c) $\mathrm{x}=1.0\left(\mathrm{Gd}_{2} \mathrm{Zr}_{2} \mathrm{O}_{7}, \mathrm{GZ}\right)$.
Table 2. Composition of $\left(\mathrm{La}_{1-\mathrm{x}} \mathrm{Gd}_{\mathrm{x}}\right)_{2} \mathrm{ZrO}_{7}$ oxides and lattice parameters (XRD patterns from sintered oxides were used for this calculation)

\begin{tabular}{ccccc}
\hline \hline$\#$ & $\mathrm{ID}$ & $\begin{array}{c}\text { Target } \\
\text { composition }\end{array}$ & $\begin{array}{c}\text { XRD-Measured lattice } \\
\text { parameter }(\mathrm{nm})\end{array}$ & Phase \\
\hline 1 & $\mathrm{LZ}$ & $\mathrm{La}_{2} \mathrm{Zr}_{2} \mathrm{O}_{7}$ & 1.080 & $\mathrm{P}$ \\
\hline \multirow{2}{*}{2} & $\mathrm{LGZ}$ & $\left(\mathrm{La}_{0.5} \mathrm{Gd}_{0.5}\right)_{2} \mathrm{Zr}_{2} \mathrm{O}_{7}$ & $\begin{array}{l}1.074(\mathrm{P}) \\
0.522(\mathrm{~F})\end{array}$ & $\mathrm{P} / \mathrm{F}$ \\
\hline 3 & $\mathrm{GZ}$ & $\mathrm{Gd}_{2} \mathrm{Zr}_{2} \mathrm{O}_{7}$ & 0.523 & $\mathrm{~F}$ \\
\hline
\end{tabular}

의하여 결정내부에 점결함(point defect)이 존재한다. 양 이온의 규칙적 배열과 특정위치의 산소 공극에 의해서 단위포 내에 초격자(superlattice)가 존재하고 이는 X-선 회절에서 부가적인 피크를 나타내게 된다. 그림 2는 $\left(\mathrm{La}_{1-\mathrm{x}} \mathrm{Gd}_{\mathrm{x}}\right)_{2} \mathrm{Zr}_{2} \mathrm{O}_{7}(\mathrm{x}=0.0,0.5,1.0)$ 산화물에 대한 하소처리 후와 소결 후의 X-선 회절 패턴 결과이다. 그림에서 보는 바와 같이 (400)과 (440) 회절 피크 사이에 나타나는 (331), (422), (511) 등의 회절피크가 fluorite 상과 비교하 여 pyrochlore 상에만 나타나는 초격자 피크들이다. LZ조 성의 경우 pyrochlore상이, GZ조성의 경우에는 fluorite상 이 단독으로 존재했고, LGZ 조성의 경우에는 pyrochlore 와 fluorite상이 혼재되어 나타났다. 각각의 상에 대해서 면지수를 표시하였는데, pyrochlore의 단위포 한 변의 길 이가 fluorite에 비해서 2 배정도 되므로 비슷한 회절각에 나타나는 회절피크의 지수값이 2 배의 인자로 나타남을 주의해야 한다.

표 2는 소결시편의 $\mathrm{X}$-선 회절패턴에서 $(222)_{\mathrm{P}} /(111)_{\mathrm{F}}$, $(400)_{\mathrm{P}} /(200)_{\mathrm{F}},(440)_{\mathrm{P}} /(220)_{\mathrm{F}},(622)_{\mathrm{P}} /(311)_{\mathrm{F}}$ 등의 주회절피크 로부터 구한 격자상수에서 $2 \theta$ 의존성을 제거한 NelsonRiley 법[14]을 사용하여 계산한 $\left(\mathrm{La}_{1-\mathrm{x}} \mathrm{Gd}_{\mathrm{x}}\right)_{2} \mathrm{Zr}_{2} \mathrm{O}_{7}(\mathrm{x}=0.0$, $0.5,1.0)$ 의 격자상수이다. $\left(\mathrm{La}_{1-\mathrm{x}} \mathrm{Gd}_{\mathrm{x}}\right)_{2} \mathrm{Zr}_{2} \mathrm{O}_{7}$ 의 격자에서 $\mathrm{La}^{3+}$ 이온(1.16 $\left.\AA\right)$ 이 반경이 약간 작은 $\mathrm{Gd}^{3+}$ 이온(1.06 $\left.\AA\right)$ 으로 치환되면서 전체 결정의 격자상수가 감소하는 경향 을 보인다.

그림 3 은 $\left(\mathrm{La}_{1-\mathrm{x}} \mathrm{Gd}_{\mathrm{x}}\right)_{2} \mathrm{Zr}_{2} \mathrm{O}_{7}(\mathrm{x}=0.0,0.5,1.0)$ 조성을 $1600^{\circ} \mathrm{C}$ 에서 2 시간동안 소결한 시편의 라만분석 결과이다. $\mathrm{Fd} \overline{3} \mathrm{~m}$ 공간군을 지니는 $\mathrm{A}_{2} \mathrm{~B}_{2} \mathrm{O}_{7}$ pyrochlore 구조는 6 개의 라만 활성화 모드를 지니는 것으로 알려져 있다. 그림에서 진동 수 $320 \mathrm{~cm}^{-1}, 410 \mathrm{~cm}^{-1}, 520 \mathrm{~cm}^{-1}$ 에 나타나는 피크들은 각각 $\mathrm{E}_{\mathrm{g}}, \mathrm{T}_{2 \mathrm{~g}}, \mathrm{~A}_{1 \mathrm{~g}}$ 모드에 해당한다[15]. $\left(\mathrm{La}_{1-\mathrm{x}} \mathrm{Gd}_{\mathrm{x}}\right)_{2} \mathrm{Zr}_{2} \mathrm{O}_{7}$ 에서 $\mathrm{Gd}$ 양이 증가할수록 라만 피크들이 넓어지고 $\mathrm{GZ}$ 조성 의 경우에는 라만피크가 사라지는데 이는 결정내의 특정 위치에 존재하는 서로 다른 $\mathrm{A}, \mathrm{B}$ 두 양이온과 산소이온 간에 결합의 진동과 관계있는 라만의 $\mathrm{E}_{\mathrm{g}}, \mathrm{T}_{2 \mathrm{~g}}, \mathrm{~A}_{\mathrm{lg}}$ 모드의 소멸을 의미하는 것으로 pyrochlore $(\mathrm{Fd} \overline{3} \mathrm{~m})$ 상에서 fluorite 


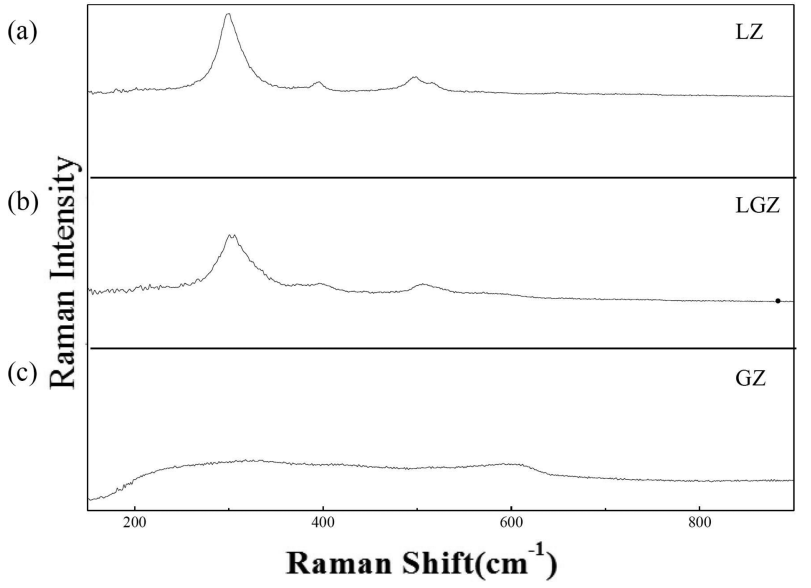

Fig. 3. Raman spectra of $\left(\mathrm{La}_{1-\mathrm{x}} \mathrm{Gd}_{\mathrm{x}}\right)_{2} \mathrm{Zr}_{2} \mathrm{O}_{7}$ samples for (a) $\mathrm{x}=\mathbf{0 . 0}$ $\left(\mathrm{La}_{2} \mathrm{Zr}_{2} \mathrm{O}_{7}, \mathrm{LZ}\right)$, (b) $\mathrm{x}=0.5(\mathrm{LGZ})$, and (c) $\mathrm{x}=1.0\left(\mathrm{Gd}_{2} \mathrm{Zr}_{2} \mathrm{O}_{7}\right.$, GZ) sintered at $1600^{\circ} \mathrm{C}$ for 2 hrs.

(a)

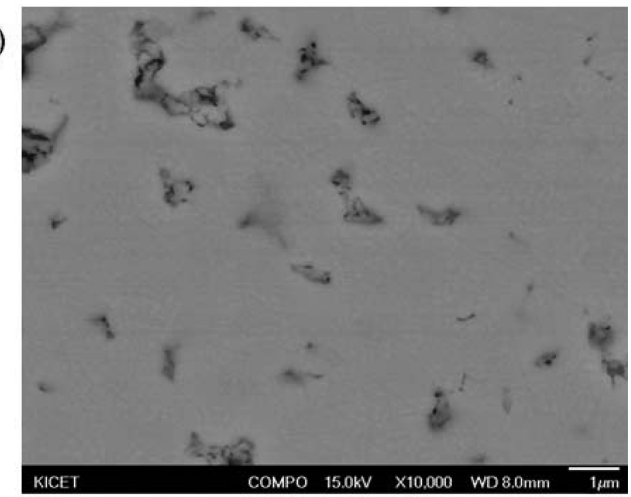

(b)

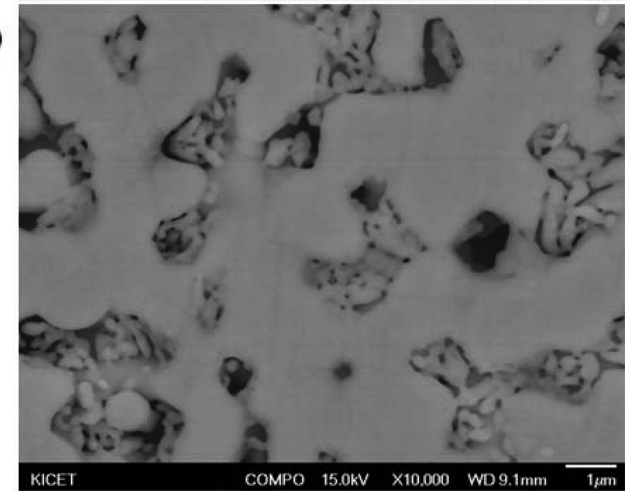

(c)

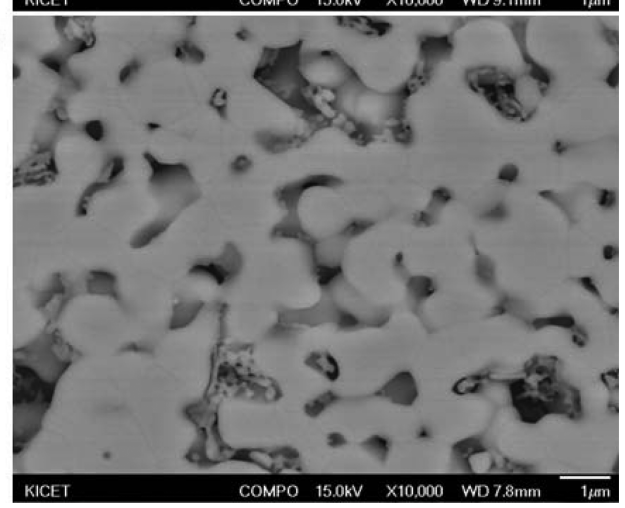

Fig. 4. SEM micrographs of $\left(\mathrm{La}_{1-\mathrm{x}} \mathrm{Gd}_{\mathrm{x}}\right)_{2} \mathrm{Zr}_{2} \mathrm{O}_{7}$ samples for (a) $\mathrm{x}=0.0\left(\mathrm{La}_{2} \mathrm{Zr}_{2} \mathrm{O}_{7}, \mathrm{LZ}\right),(\mathrm{b}) \mathrm{x}=0.5(\mathrm{LGZ})$, and (c) $\mathrm{x}=1.0\left(\mathrm{Gd}_{2} \mathrm{Zr}_{2} \mathrm{O}_{7}\right.$, GZ) sintered at $1600^{\circ} \mathrm{C}$ for $2 \mathrm{hrs}$.
$(\mathrm{Fm} \overline{3} \mathrm{~m})$ 상으로의 상변화를 나타내며 이는 X-선 회절결과 와 일치한다.

그림 4 는 $\left(\mathrm{La}_{1-\mathrm{x}} \mathrm{Gd}_{\mathrm{x}}\right)_{2} \mathrm{Zr}_{2} \mathrm{O}_{7}(\mathrm{x}=0.0,0.5,1.0)$ 조성을 $1600^{\circ} \mathrm{C}$ 에서 2 시간동안 소결한 시편의 단면 미세구조이다. 시편 전반에 걸쳐서 상당한 양의 기공이 존재하여 입자크 기 등을 관찰하는 것은 어려웠다. 소결시편을 $1400^{\circ} \mathrm{C}$ 의 로에 각각 10 시간과 100 시간 동안 유지하고 고온에 장 시간 노출되었을 때 결정상과 기공의 변화를 관찰하였다. 그림 5 와 6 은 $\left(\mathrm{La}_{1-\mathrm{x}} \mathrm{Gd}_{\mathrm{x}}\right)_{2} \mathrm{Zr}_{2} \mathrm{O}_{7}(\mathrm{x}=0.0,0.5,1.0)$ 조성을 $1600^{\circ} \mathrm{C}$ 에서 2 시간동안 소결하고 후속으로 열차폐코팅에 사용이 예상되는 조건인 $1400^{\circ} \mathrm{C}$ 에서 10 시간, 100 시간 열처리한 시편의 상대밀도와 X-선 격자상수 변화이다. $\mathrm{Gd}$ 이 존재하는 경우에 상대밀도가 낮게 나타나고 후속열처 리에도 밀도가 크게 증가되지 않아서 $\left(\mathrm{La}_{1-\mathrm{x}} \mathrm{Gd}_{\mathrm{x}}\right)_{2} \mathrm{Zr}_{2} \mathrm{O}_{7}$ 조

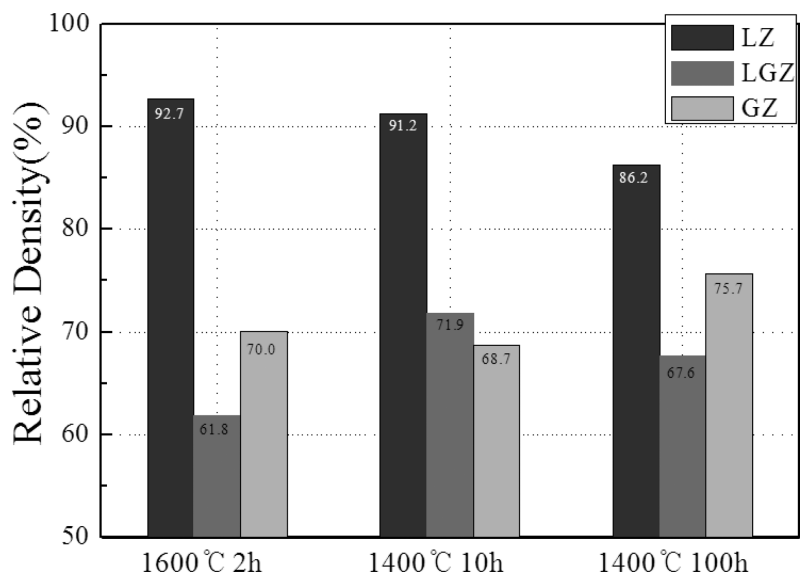

Fig. 5. Relative density values of $\left(\mathrm{La}_{1-\mathrm{x}} \mathrm{Gd}_{\mathrm{x}}\right)_{2} \mathrm{Zr}_{2} \mathrm{O}_{7}$ samples for $x=0.0\left(\mathrm{La}_{2} \mathrm{Zr}_{2} \mathrm{O}_{7}, \mathrm{LZ}\right), \mathrm{x}=0.5(\mathrm{LGZ})$, and $\mathrm{x}=1.0\left(\mathrm{Gd}_{2} \mathrm{Zr}_{2} \mathrm{O}_{7}\right.$, GZ) sintered at $1600^{\circ} \mathrm{C}$ for $2 \mathrm{hrs}$ and post-heat treated at $1400^{\circ} \mathrm{C}$ for 10 hrs or 100 hrs.

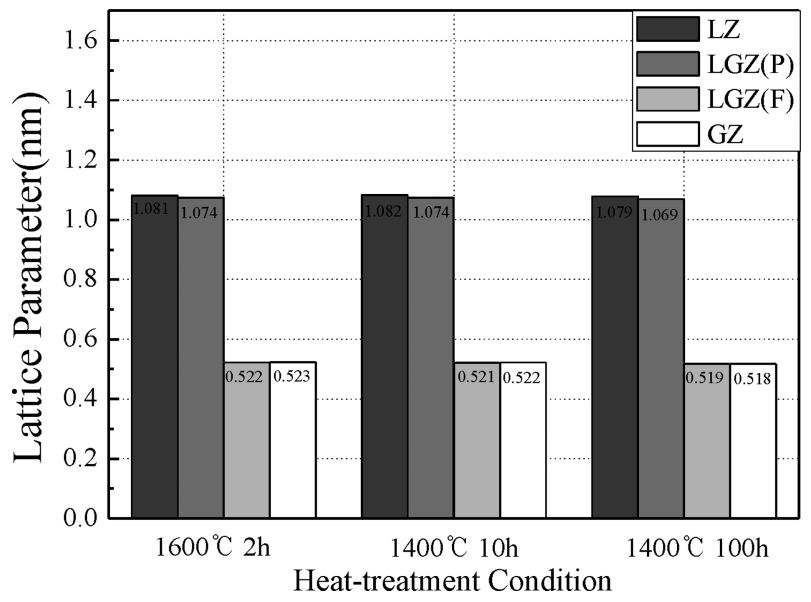

Fig. 6. Lattice parameter values of $\left(\mathrm{La}_{1-\mathrm{x}} \mathrm{Gd}_{\mathrm{x}}\right)_{2} \mathrm{Zr}_{2} \mathrm{O}_{7}$ samples for $x=0.0\left(\mathrm{La}_{2} \mathrm{Zr}_{2} \mathrm{O}_{7}, \mathrm{LZ}\right), \mathrm{x}=0.5(\mathrm{LGZ})$, and $\mathrm{x}=1.0\left(\mathrm{Gd}_{2} \mathrm{Zr}_{2} \mathrm{O}_{7}\right.$, GZ) sintered at $1600^{\circ} \mathrm{C}$ for $2 \mathrm{hrs}$ and post-heat treated at $1400^{\circ} \mathrm{C}$ for $10 \mathrm{hrs}$ or $100 \mathrm{hrs}$. 


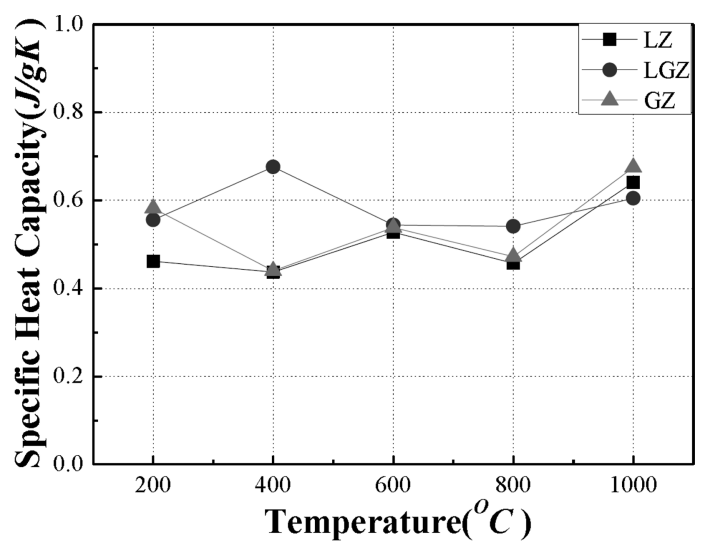

(a)

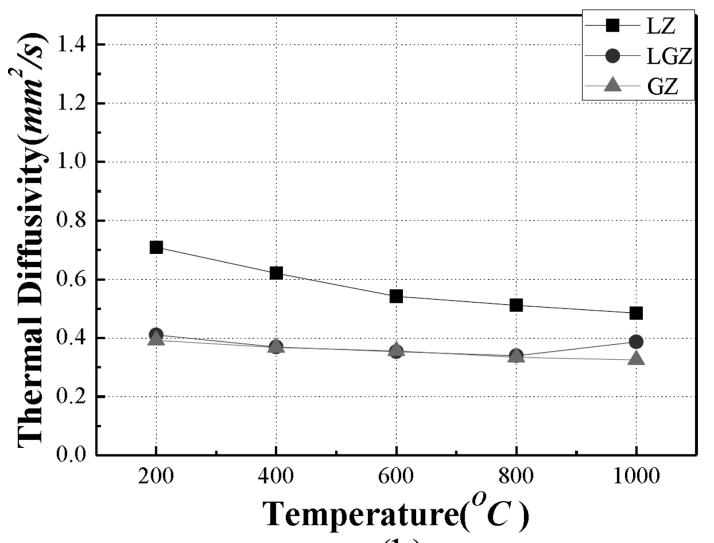

(b)

Fig. 7. (a) specific heat capacity $\left(C_{p}\right)$ and (b) thermal diffusivity $(\lambda)$ of sintered $\left(\mathrm{La}_{1-\mathrm{x}} \mathrm{Gd}_{\mathrm{x}}\right)_{2} \mathrm{Zr}_{2} \mathrm{O}_{7}$ oxides with temperature.

성이 고온에서 소결로 인한 열전도도 변화가 크지 않을 것으로 예측된다. 격자상수의 경우에는 후속열처리에 의 해서 크게 변화하지 않았는데 이는 하소 후 $1600^{\circ} \mathrm{C}$ 에서 2 시간동안의 소결에 의해서 생성된 상이 고온에서 안정함 을 나타낸다.

\section{2. $\left(\mathrm{La}_{1-\mathrm{x}} \mathrm{Gd}_{\mathrm{x}}\right) \mathrm{Zr}_{2} \mathrm{O}_{7}$ 산화물의 고온 열전도도 특성}

그림 7, 8 은 $\left(\mathrm{La}_{1-\mathrm{x}} \mathrm{Gd}_{\mathrm{x}}\right)_{2} \mathrm{Zr}_{2} \mathrm{O}_{7}$ 산화물을 $1600^{\circ} \mathrm{C}$ 에서 2 시 간 동안 소결한 시편의 비열, 열확산도, 열전도도이다. 본 연구에서는 비열과 열확산도를 모두 레이저플래시법 (laser flash analysis, LFA)을 이용하여 측정하였는데 비열 의 경우 알루미나와 같이 비열이 알려져 있는 표준시편과 시험시편의 상대적인 온도상승을 비교하여 구하고 열확산 도의 경우 두께를 감안하여 시편을 통한 열전도 시간으로 부터 측정한다. 측정된 겉보기 밀도, 비열, 열확산도를 이 용하여 열전도도를 계산하였다.

$\left(\mathrm{La}_{1-\mathrm{x}} \mathrm{Gd}_{\mathrm{x}}\right)_{2} \mathrm{Zr}_{2} \mathrm{O}_{7}$ 조성의 경우에는 온도에 의존성이 두드 러지지 않으며 0.8 1.5 W/mK 정도의 열전도도를 나타냈 다. 특히 열전도도의 온도의존성은 포논산란의 기여가 다 름을 보여주는데 일반적으로 세라믹에서 나타나는 $1 / \mathrm{T}$ 의

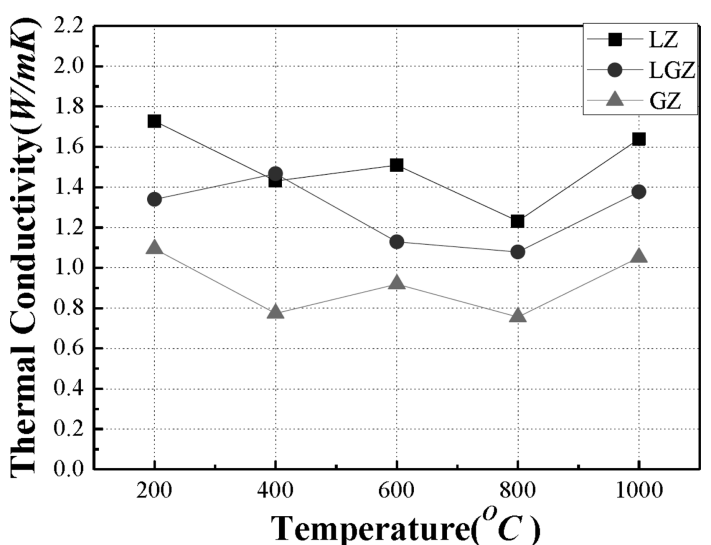

(a)

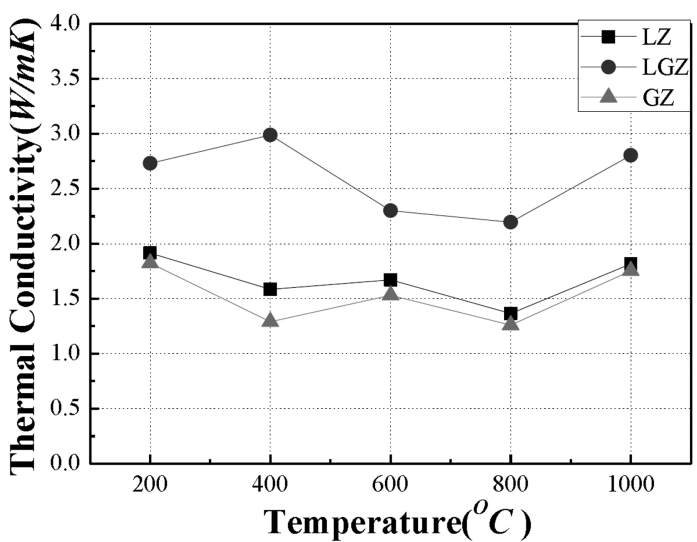

(b)

Fig. 8. Thermal conductivity values of sintered $\left(\mathrm{La}_{1-\mathrm{x}} \mathbf{G d}_{\mathrm{x}}\right)_{2} \mathrm{Zr}_{2} \mathrm{O}_{7}$ oxides with temperature: (a) as-calculated and (b) porositycalibrated.

존성은 움클랍 과정(Umklapp process)[16]으로 알려져 있 는 본래의 열전도(intrinsic thermal conduction)를 나타내며, 온도의존성이 거의 없는 경우에는 구조 내의 결함에 의한 포논산란을 나타낸다[3]. 다결정 구조의 포논산란을 일으 키는 결함으로는 기공, 입계, 점결함 등이 있다. 이중 기공 에 의한 영향은 열전도도의 측정값 $\left(\mathrm{K}_{\text {measured }}\right)$ 과 소재 본래 의 열전도도 $\left(\mathrm{K}_{\mathrm{true}}\right)$ 간의 관계식[17]으로 나타낼 수 있다.

$$
\mathrm{K}_{\text {measured }} / \mathrm{K}_{\text {true }}=1-\frac{4}{3} \varphi \quad(\varphi \text { 는 기공율 })
$$

그림 8(b)에서와 같이 기공상태를 보정한 재료 본래의 열전도도를 살피면 $\mathrm{LZ}$ 와 $\mathrm{GZ}$ 조성이 상대적으로 낮은 열 전도도를 나타냄을 알 수 있으며 미세구조에서 기공이 많 아 입자크기를 정확히 관측할 수 없어서 입계와 점결함에 의한 포논산란의 정도를 명확히 분리하는 것은 어려웠다. 추후에 동일한 완전치밀화된 시편을 제조하여서 기공의 영향을 제거하고 조성과 입계에 의한 영향을 살필 수 있 다면 결정구조 및 점결함과 조성에 의한 본래의 열전도도 간의 관계를 좀더 정확히 고찰할 수 있을 것이다. 
문헌에 알려진 치밀화된 $\mathrm{YSZ}$ 의 상온에서 $1000^{\circ} \mathrm{C}$ 까지의 열전도도가 2.0 2.5 W/mK인 것을 감안하면[18] 본 연구 에서 살펴본 $\left(\mathrm{La}_{1-\mathrm{x}} \mathrm{Gd}_{\mathrm{x}}\right)_{2} \mathrm{Zr}_{2} \mathrm{O}_{7}$ 산화물 소재의 열전도도가 YSZ 대비 근사하거나 낮은 값을 나타내어 열차폐 효과가 우수할 것으로 기대된다.

\section{4. 결 론}

본 연구에서는 $\mathrm{La}_{2} \mathrm{O}_{3}, \mathrm{Gd}_{2} \mathrm{O}_{3}, \mathrm{ZrO}_{2}$ 3종의 산화물을 이 용하여 $\left(\mathrm{La}_{1-\mathrm{x}} \mathrm{Gd}_{\mathrm{x}}\right)_{2} \mathrm{Zr}_{2} \mathrm{O}_{7}(\mathrm{x}=0.0,0.5,1.0)$ 복합산화물을 합 성하고 상형성과 고온 열전도도 특성을 살폈다. $1400^{\circ} \mathrm{C}$ 하소처리와 $1600^{\circ} \mathrm{C}$ 소결 후에는 조성에 따라 LZ조성의 경우 pyrochlore상이, GZ조성의 경우에는 fluorite상이, LGZ 조성의 경우에는 pyrochlore와 fluorite상이 혼재되어 나타났다. 제조된 $\left(\mathrm{La}_{1-\mathrm{x}} \mathrm{Gd}_{\mathrm{x}}\right)_{2} \mathrm{Zr}_{2} \mathrm{O}_{7} 1.0 \sim 2.5 \mathrm{~W} / \mathrm{mK}$ 의 열전 도도를 나타내어 YSZ를 대체하는 열차폐코팅 소재로서의 응용이 가능할 것으로 사료된다.

\section{감사의 글}

본 연구는 지식경제부 소재원천기술개발사업의 연구비 지원으로 수행되었습니다.

\section{참고문헌}

[1] D. R. Clarke and C. G Levi: Annu. Rev. Mater. Res., 33 (2003) 383.

[2] G. Carlos and C. G. Levi: Curr. Opin. Solid State Mater. Sci., 8 (2004) 77.
[3] D. R. Clarke: Surf. Coat. Technol., 163-164 (2003) 67.

[4] W. Pan, S. R. Phillpot, C. Wan, A. Chernatynskiy and Z. Qu: Mater. Res. Soc. Bull., 37 (2012) 917.

[5] X. Q. Cao, R. Vassen and D. Stoever: J. Euro. Ceram. Soc., 24 (2004) 1.

[6] J. Wu, X. Z. Wei, N. P. Padture, P. G. Klemens, M. Gell, E. Garcia, P. Miranzo and M. I. Osendi: J. Am. Ceram. Soc., 85 (2002) 3031.

[7] P. K. Schelling, S. R. Phillpot and R. W. Grimes: Philos. Mag. Lett., 84 (2004) 127.

[8] B.-C. Shim, K.-H. Kwak, S.-M. Lee, Y.-S. Oh, H.-T. Kim, B.-K. Jang and S. Kim: J. Kor. Powd. Met. Inst., 17 (2010) 148 (Korean).

[9] S. Kim, S.-M. Lee, Y.-S. Oh, H.-T. Kim and B.-K. Jang: J. Kor. Powd. Met. Inst., 18 (2011) 568 (Korean).

[10] M. A. Subramanian, G Aravamudan and G V. Subba Rao: Prog. Solid St. Chem., 15 (1983) 55.

[11] L. Minervini and R. W. Grimes: J. Am. Ceram. Soc., 83 (2000) 1873.

[12] A. Chartier, C. Meis, J. P. Crocombette, L. R. Corrales and W. J. Weber: Phys. Rev. B, 67 (2003) 174102.

[13] D. R. Clarke and S. R. Phillpot: Mater. Today, 8 (2005) 25.

[14] J. B. Nelson and D. P. Riley: Proc. Phys. Soc., 57 (1945) 160.

[15] N. J. Hess, B. D. Begg, S. D. Conradson, D. E. McCready, P. L. Gassman and W. J. Weber: J. Phys. Chem., B, 106 (2002) 4663.

[16] C. Kittel: Introduction to Solid State Physics, 8th Ed., John Wiley \& Sons, Inc. (2005) 125.

[17] J. Wu, N. P. Paolture, P. G. Klemens, M. Gells, E. Garcia, P. Miranzo and M. I. Osendi: J. Mater. Res., 17 (2002) 3193.

[18] M. R. Winter and D. R. Clarke: J. Am. Ceram. Soc., 90 (2007) 533. 